Egypt. J. of Appl. Sci., 35 (12) 2020

$16-41$

\title{
ROLE OF FILTER MUD, AMINO ACIDS, ACTIVE YEAST AND SEAWEED EXTRACT IN ENHANCING GROWTH AND SOME CHEMICAL CONSTITUENTS OF KHAYA SENEGALENSIS SEEDLINGS
}

\author{
Abo-Quta, W.M.H.*; A.F. Ali *; A.A. Ahmed** and E.H. Amer* \\ * Dept. Horticulture, Fact. Agric., Al-Azhar University, Assyut, Egypt. \\ ** Woody trees Res. Dept., Agric. Res. Center, Giza, Egypt.
}

Key Words: Khaya senegalensis, filter mud, amino acids, active yeast and seaweed extract.

\section{ABSTRACT}

This research was carried out at the experimental Farm, Faculty of Agriculture, Al-Azhar University, Assiut, during the two successive seasons of 2018 and 2019 aiming to study the influence of filter mud as organic manure stimulant substances namely (amino acids \{tryptophan + methionine \}, active yeast and seaweed extract), as well as, their Interactions on plant growth traits and chemical constituents of Khaya (Khaya senegalensis) seedlings. The soil of Khaya seedlings was supplied with filter mud at $0,18,36$ and $54 \mathrm{~g} / \mathrm{bag}$ and the seedlings were sprayed with stimulant substances, whereas the treatments of these materials were: control, amino acids at $100 \mathrm{ppm}$, active yeast at $5 \mathrm{~g} / \mathrm{l}$, seaweed extract at $3 \mathrm{ml} / 1$, amino acids + active yeast, seaweed + active yeast, amino acids + seaweed extract and amino acids + active yeast + seaweed extract. The obtained results indicated that applying filter mud at all levels led to a significant increase in vegetative growth traits (stem length, stem diameter, leaves dry weight / seedling and stem dry weight / seedling) as well as, the elements of N, P and K \%, except for the low level of filter mud (18 g/bag), in some cases. the highest values of these parameter were detected when adding filter mud at the high level (54 g /bag). Foliar spray with the examined stimulant Substances, in many cases, either separately or mixed resulted a significant augment in the studied traits. Clearly, bitter results were noticed by treating the seedlings with the triple combined treatment (amino acids + active yeast + seaweed extract) and the double combined treatment (amino acids + seaweed extract). the most of combined treatments significantly increased the growth traits and $\mathrm{N}, \mathrm{P}$ and $\mathrm{K} \%$. Obviously, the most effective combined treatments of examined characters, in many cases were detected from supplying the seedlings with the high level of filter mud ( $54 \mathrm{~g} / \mathrm{bag}$ ) followed by filter mud at the moderate one ( $36 \mathrm{~g} / \mathrm{bag}$ ) in combination with the triple combined treatment (amino acids + active yeast + seaweed extract) and the double combined treatment (amino acids + seaweed extract). 


\section{INTRODUCTION}

Khaya (khaya senegalensis A. Juss) belongs to family Meliaceae it is one of very important woody trees it is semi evergreen and native to tropical west Africa it grows well in upper Egypt as shade and avenye tree. The wood is hard, heavy and durable and it can be easily manufacture, varnished, and glued It is used in furniture , manufacture, musical instruments, lumber works, boxes, carts, plywood, veneers ships and boots (Badarn et al. 1978 and El-Hadidy and Boluos, 1979). Filter mud is one of organic fertilizers, it is a local organic manure and it is useful in stimulating the growth and productivity.

Organic agriculture is based on minimizing the application of external inputs and avoiding the use of synthetic fertilizers and pesticides (Galal and Ali, 2004). Organic manures canable promoting microbial biomass (Suresh et al. 2004). Also, Douda et al. (2008) emphasized that organic manures can serve as alternative to mineral fertilizers for improving the soil structure.

Many researchers studied the positive effect of organic fertilization on plant growth and chemical constituents of some woody trees such as, Ali $\boldsymbol{e t}$ al.(2001) and El- Sayed and Abdou (2002) on khaya senegalensis, Ali et al. (2002), Ahmed et al. (2006) and Mahmoud (2014) on Populus sp., Wroblewska et al. (2009) on salix purpurea, William et al. (2012), Abou El- Makarem (2016) and Hussein (2019) on Moringa, Ali et al. ( 2019) and Abdullatif (2019) on coriander, Ali et al. (2020), Abd El- Raheem (2020) on Taxodium distichum and (Abdullatif 2019) on coriander.

Amino acids as organic nitrogenous compounds are the building blocks in synthesis of protein. They can stimulate cell growth and protect the plants from ammonie toxicity (Smith, 1982). The role of amino acids in enhancing the growth of some plants was examined by many authors such as, Ali et al. (2006) and Yassen et al. (2010) on anise, Attoa et al.(2002) on Iberis amara, Abd El- Aziz et al. (2010) on Thuja orientalis, Ahmed et al. (2011) on Hibiscus sabdariffa, Abd El- Rahman et al. (2008) on Fennel, Al- Qubia (2012) on Helianthus annus and Aly et al. (2014) on Kapok, Ali et al. (2016) and Abd El- Rahman(2016) on chamomile. As for the stimulating influence of amino acids on some chemical constituents of plants have to be discussed by many workers such as Abd El- Aziz et al. (2010) on Thuja orientalis, Talaat (2005) on pelargonium gravedens, Yassen et al. (2010) on anise, Ali and Hassan (2013) on Tagetes erecta, Abd El- Rahman et al (2008) on fennel, Abd El- Rahman (2016) on chamomile and Abdullatif (2019) on coriander.

The application of active yeast extract (saccharomyces cerveace) as bio-stimulant is important for horticultural plants to obtain high quality and quantity of products whereas yeast contains nutritional elements, organic compounds and natural hormones. The capability of active yeast on 
improving the growth and some chemical constituents was declared by many investigators such as (Ahmed et al. 1997) and Akl et al. (1997) on grape vine, Ahmed et al.( 1998) on Hisbiscus Sabdariffa, Ali (2001) on calendula officinalis, Ahmed (2002) on Leucaena lcucocephala, Ahmed (2014) on Kapok and Ali et al.( 2020) on Taxodium distichum.

Seaweed extracts contain phytohormones (gibberellins, IAA and cytokinins) macro and Micronutrients as Will as, organic substances like vitamins, Amino acids and fatty acids (Chapman and Chapman, 1980) the addition of seaweed extract augment the uptake of nutrients from the soil (Verkij, 1992 and Turan and Kose, 2004) and Promotes the growth and yield (Ramarao, 1991). Farthermore, (Zhang 2000) claimed that seaweed extract enhances tolerance to environmental stress. The enhancement in the growth and chemical constituents of some tress was insured by many authors such as Hegab et al.( 2005) and Hassan (2008) on Balady Orange, Gamal (2006) and Ahmed et al.(2008) on washingtonia navel orange trees, Ismail et al .(2011) on Bitter orange seedlings, Abdel - Aal et al.( 2012) on Balady Mandarin, Haggag et al. (2014) on olive seedlings, A-Rawi et al. (2016) on peach El- Salhy et al. (2017) on Balady Mandrin Hamed (2017) on anise, Ali et al. (2018) and Farghly (2018) on Kapok tree seedlings.

The objective of this investigation was examine the influence of filter mud as organic fertilizer and bio stimulant substances (amino acids [Tryptophan and methionine], active yeast and seaweed extract), as well as their interactions on plant growth and some chemical constituents of khaya senegalnsis seedlings to find out the most suitable treatment for enhancing these traits.

\section{MATERIALS AND METHODS}

The present study was conducted at the Experimental Farm, Fac. of Agric., Al-Azhar Univ., Assiut, during the successive seasons of 2018 and 2019 to determine the effect of filter mud as organic manure and stimulant substances, as well as, their interactions on plant growth and chemical constituents of Khaya (Khaya Senegalensis) seedlings. A split plot design with three replicates was used in this experiment. Organic fertilization treatments considered the main plots (A) while stimulant substance treatments were the sub-plots (B). Khaya (Khaya Senegalensis) seedlings were obtained from Hort. Res. Inst., Giza, Egypt.

One year old of Khaya seedlings, healthy and uniform, average seedling length was $24-26 \mathrm{~cm}$. and $0.50-0.53 \mathrm{~cm}$. diameter for both seasons, respectively. The seedlings were planted on March $7^{\text {th }}$ for the two seasons in polyethylene bags $\left(25^{*} 30 \mathrm{~cm}\right.$.).

Each bag was filled with $10 \mathrm{Kg}$ of loamy soil and contained one seedling. Each replicate contained 5 seedlings. Chemical properties of the soil used were determined according to Jackson (1973) and are shown in table (1). Filter mud was obtained from Sugar and Integrated Industries 
Company, Nag Hammadi, Egypt. Chemical properties of filter mud were determined according to Black $\boldsymbol{e t}$ al., (1965) and are shown in table (2). Filter mud levels were $0,18,36$ and $54 \mathrm{~g} / \mathrm{bag}$ and added with the soil before planting the seedlings. Stimulant substances treatments were control, amino acids (tryptophan and methionine) at $100 \mathrm{ppm}$, active yeast at $5 \mathrm{~g} / \mathrm{l}$, seaweed extract at $3 \mathrm{ml} / \mathrm{l}$, amino acids + active yeast, seaweed extract + active yeast, amino acids + seaweed extract and amino acids + active yeast + seaweed extract. Algeser product contains seaweed extract, chemical properties of seaweed extract were shown in table (3). These substances were applied as foliar spray three times at two weeks interval starting April $27^{\mathrm{th}}$ of the two season, one day period was allowed between spraying these stimulant substances. All other agricultural practices were followed as usual. At the end of the experiment (the first week of November) for both seasons, the following data were recorded: stem length $(\mathrm{cm}$.$) , stem diameter (\mathrm{cm}$.$) , leaves dry weight (\mathrm{g}) /$ seedling, stemdry Also, the three examined elements (N, P and $\mathrm{K}) \%$ were estimated in the dried leaves as follows: Nitrogen (\%) was determined according to the method of modified micro Kjeldahl as described by Wilde et al. (1985). Phosphorus (\%) was estimated colorimetrically according to Chapman and Pratt (1975). And Potassium (\%) was determined by Flame photometer according to Cottenie et al. (1982). The obtained data were tabulated and statistically analyzed according to MSTATE-C (1986) using L.S.D. at 5\% to know the differences among all treatments according to Mead et al. (1993).

Table (1): The physical and chemical properties of the used Soil (Average for the two seasons).

\begin{tabular}{|c|c|c|c|c|c|c|c|}
\hline \multirow[b]{2}{*}{ Texture } & \multirow[b]{2}{*}{$\begin{array}{c}\text { PH } \\
(1: 2.5)\end{array}$} & \multirow{2}{*}{$\begin{array}{c}\text { E.C. } \\
(\mathbf{m} . \mathbf{m o h s} \\
/ \mathbf{c m})\end{array}$} & \multirow[b]{2}{*}{$\begin{array}{c}\mathrm{CaCo}_{3} \\
\%\end{array}$} & \multirow[b]{2}{*}{$\underset{\%}{\text { O.M }}$} & \multirow{2}{*}{$\begin{array}{c}\text { Total } \\
\mathbf{N} \\
\mathbf{\%} \\
\end{array}$} & \multicolumn{2}{|c|}{ Available } \\
\hline & & & & & & $\begin{array}{c}\mathbf{P} \\
\mathbf{p p m}\end{array}$ & $\begin{array}{c}\mathrm{K} \\
\text { (mg/100g soil) }\end{array}$ \\
\hline Loamy & 7.5 & 2.03 & 2.25 & 0.54 & 0.10 & 0.15 & 3.1 \\
\hline
\end{tabular}

Table (2): Chemical characteristics of filter mud applied in this experiment. (Average for the two seasons).

\begin{tabular}{||c||c|}
\hline Content & Compost (plant residues) \\
\hline Total nitrogen \% & 2.85 \\
\hline Total phosphorus \% & 2.3 \\
\hline Total potassium\% & 0.75 \\
\hline Zn ppm & 110 \\
\hline Mn ppm & 295 \\
\hline Fe ppm & 4560 \\
\hline Cu ppm & 193 \\
\hline E.C.(ds $/ \mathbf{m})$ & 3.5 \\
\hline Organic matter \% & 35.0 \\
\hline C : N Ratio & $\mathbf{8 . 3}$ \\
\hline Organic carbon \% & 23.6 \\
\hline PH & 7.3 \\
\hline
\end{tabular}


Table (3): Chemical properties of seaweed extract used in the present study.

\begin{tabular}{|c|c|}
\hline Characteristics & Value \\
\hline Moisture \% & 6.0 \\
\hline Organic matter \% & $45-60$ \\
\hline Inorganic matter \% & $45-60$ \\
\hline Carbohydrates \% & $\mathbf{3 5}-\mathbf{5 0}$ \\
\hline Protein \% & $6-8$ \\
\hline Mannitol \% & $4-7$ \\
\hline Aliginic acid & $10-20$ \\
\hline Total N \% & $1-1.5$ \\
\hline Total P \% & $0.02-0.09$ \\
\hline Total K \% & $1-1.2$ \\
\hline Са \% & $0.2-1.5$ \\
\hline Mg \% & $0.5-0.9$ \\
\hline $\mathrm{S} \%$ & $3-9$ \\
\hline Zn ppm & $10-100$ \\
\hline Mn ppm & $5-12$ \\
\hline Fe ppm & $50-200$ \\
\hline Cu ppm & $1-6$ \\
\hline B ppm & $20-100$ \\
\hline Mo ppm & $1-5$ \\
\hline IAA \% & 0.03 \\
\hline Cytokinine \% & 0.02 \\
\hline IBA \% & 0.01 \\
\hline
\end{tabular}

\section{RESULTS AND DISCUSSION}

Stem length:

The presented data in table (4) revealed that supplying khaya seedlings with organic manure as filter mud at all levels led to a significant increase in stem length as compared to the check treatment during the two experimental seasons. Significant differences among all filter mud levels in both seasons were detected, except for between the high and moderate levels, during the two seasons. Therefore better results of stem length were obtained from using the moderate level (36 $\mathrm{g} /$ seedling) which increased it by $27.2 \%$ and by $28.5 \%$ over the check treatment, in the first and second seasons, respectively.

The increscent of stem length as a result of applying organic manure was also reported by Ali et al. (2001) and El-Sayed and Abdou (2002) on khaya senegalansis seedling William et al (2012), Abou - ElMakarem (2016) and Hussien (2019) on moringa and Ali et al(2020) and Abd El-Raheem (2020) on Taxodium distichum seedling.

In regard to stimulant substance treatments, data in table (4) cleared that all of them, except for amino acids treatment in both seasons caused a significant augment in stem length comparing to untreated ones. The use of triple combined treatment (amino acids + active yeast + seaweed extract) and double combined treatment (amino acids+ seaweed 
extract) gave the longer stems reached $31.6 \%, 24.8 \%, 24.5 \%$ and $18.9 \%$ over no sprayed plants, during the two seasons, respectively.

Table (4): The influence of filter mud level, amino acids, active yeast and seaweed extract on stem length $(\mathrm{cm}$.) of khaya senegalensis seedlings during the two season of 2018 and 2019.

\begin{tabular}{|c|c|c|c|c|c|}
\hline \multicolumn{6}{|c|}{ First season } \\
\hline \multirow{2}{*}{$\begin{array}{c}\text { Simulant substances } \\
\text { treatment (B) }\end{array}$} & \multicolumn{4}{|c|}{ Filter mud g/seedling (A) } & \multirow{2}{*}{$\begin{array}{c}\text { Mean } \\
\text { (B) }\end{array}$} \\
\hline & $\mathbf{0}$ & 18 & 36 & 54 & \\
\hline Control & 90.7 & 93.0 & ב107.0 & 1112.3 & $10 \mathbf{1 0 0 . 8}$ \\
\hline $\begin{array}{l}\text { Amino acids } \\
100 \mathrm{ppm}\end{array}$ & 95.3 & 100.3 & 117.5 & 120.1 & 108.3 \\
\hline Active yeast $5 \mathrm{~g} / \mathrm{L}$ & 99.3 & 110.6 & 129.3 & 135.0 & 118.6 \\
\hline Seaweed extract $3 \mathrm{ml} / \mathrm{L}$ & 95.0 & 105.3 & 130.0 & 137.6 & 117.0 \\
\hline $\begin{array}{c}\text { Amino acids + Active } \\
\text { yeast }\end{array}$ & 100.5 & 115.0 & 125.8 & 129.5 & 117.7 \\
\hline $\begin{array}{c}\text { Seaweed extract+ Active } \\
\text { yeast }\end{array}$ & 96.3 & 118.5 & 131.0 & 133.0 & 119.7 \\
\hline $\begin{array}{c}\text { Amino acids + Seaweed } \\
\text { extract }\end{array}$ & 105.0 & 120.3 & 132.5 & 144.9 & 125.7 \\
\hline $\begin{array}{c}\text { Am. acids + Ac. yeast + } \\
\text { Seaweed extract }\end{array}$ & 114.0 & 126.0 & 140.0 & 150.7 & 132.7 \\
\hline בMean (A) & 99.5 & 111.1 & 12126.6 & 132.9 & \\
\hline L.S.D (0.05) & \multicolumn{2}{|c|}{$\mathrm{A}=7.1$} & $\mathrm{B=10.4}$ & \multicolumn{2}{|c|}{$\mathrm{AB}=20.7$} \\
\hline \multicolumn{6}{|c|}{ Second season } \\
\hline \multirow{2}{*}{$\begin{array}{c}\text { Simulant substances } \\
\text { treatment }(\mathrm{B})\end{array}$} & \multicolumn{4}{|c|}{ Filter mud g/seedling (A) } & \multirow{2}{*}{$\begin{array}{c}\text { Mean } \\
\text { (B) }\end{array}$} \\
\hline & $\mathbf{0}$ & 18 & 36 & 54 & \\
\hline Control & 85.1 & 97.0 & 111.4 & 115.2 & 102.2 \\
\hline Amino acids100 ppm & 86.0 & 94.3 & 115.3 & 127.0 & 105.7 \\
\hline Active yeast $5 \mathrm{~g} / \mathrm{L}$ & 96.0 & 106.4 & 125.0 & 130.5 & 114.5 \\
\hline Seaweed extract $3 \mathrm{ml} / \mathrm{L}$ & 95.5 & 108.0 & 120.0 & 133.0 & 114.1 \\
\hline $\begin{array}{c}\text { Amino acids + Active } \\
\text { yeast }\end{array}$ & 105.0 & 110.7 & 122.5 & 136.7 & 118.7 \\
\hline $\begin{array}{c}\text { Seaweed extract+ Active } \\
\text { yeast }\end{array}$ & 103.7 & 122.0 & 130.4 & 138.0 & 123.5 \\
\hline $\begin{array}{c}\text { Amino acids + Seaweed } \\
\text { extract }\end{array}$ & 100.0 & 108.7 & 135.6 & 141.7 & 121.5 \\
\hline $\begin{array}{l}\text { Am. acids + Ac. yeast }+ \\
\text { Seaweed extract }\end{array}$ & 105.5 & 120.0 & 138.0 & 145.1 & 127.2 \\
\hline $\begin{array}{c}\text { Mean (A) } \\
\end{array}$ & 97.1 & $\begin{array}{l}108.4 \\
\end{array}$ & 124.8 & 10133.4 & \\
\hline L.S.D (0.05) & \multicolumn{2}{|c|}{$\mathrm{A}=\mathbf{1 0 . 8}$} & $\mathrm{B}=9.5$ & \multicolumn{2}{|c|}{$\mathrm{AB}=\mathbf{1 9 . 0}$} \\
\hline
\end{tabular}

The promoting effect of amino acids on stem length was also insured by Attoa et al (2002) on Iberis amara, Abd El-Azziz et al .(2010) on Thuja orientalis, Al-Qubia (2012) on Helianthus annus Mustafa and Ebeid (2013) on Albizza lebbekand and Taxodium distichum and, Aly et al (2014) on Kapok seedlings .

The stimulating effect of active yeast on stem length was also demonstrated by Ahmed (2002) on Leucaena lencucephala, Ali (2001) on calendula officinalis, Al- Qubaie (2002) on rue and Ahmed (2014) on Kapok seedlings. 
The role of seaweed extract in increasing stem length was also revealed by Haggag et al. (2014) on olive seedlings, Hassan (2015) on dill, Hamed (2017) on anise, Akila and Jeyadoss (2010) on Helianthus annus, Ali et al. (2018) and Farghaly (2018) on Kapok.

As for the interaction, it was significant effect on stem length of khaya during the two growing seasons (table 4). It is obvious that the addition of most of combined treatments resulted a significant augment in stem length, in both seasons, as compared to untreated plants. The most effective treatments in increasing such parameter were detected when using filter mud at the high level $(54 \mathrm{~g} /$ seedling) in combination with triple combined (amino acids + active yeast + seaweed extract) followed by amino acids + seaweed extract or seaweed + active yeast and the moderate level (36 g/seedling) with the same three previous combined treatments in comparisons with other combination treatments during the two growing seasons.

\section{Stem diameter:}

The given results in table (5) showed that receiving khaya seedlings filter mud at all levels, in both seasons except for the low level (18 $\mathrm{g} /$ seedling) in the second seasons led to a significant increase in stem diameter as compared to unfertilized ones. Such parameter was gradual significantly augmented with increasing filter mud level in both seasons, therefore, the thicker plants were obtained when treating khaya seedlings with filter mud at the high level (54 g/seedling) as ranged $24 \%$ and $18.8 \%$ over the check treatment in the first and second seasons, respectively.

The capability of organic manure on augmenting stem diameter was also obtained by Ali et al. (2001) and El-Sayed and Abdou (2002) on khaya senegalansis, Abou - El-Makarem (2016) and Hussein (2019) on moringa and Ali et al (2020) and Abd El-Raheem (2020) on Taxodium distichum seedling .

Concerning stimulant substance treatments, the data postulated that foliar spray with the examined substances either double or triple combined treatments, in both seasons, resulted a significant increase in stem diameter comparing to no sprayed plants. The application of triple combined treatment (amino acids+ active yeast+ seaweed extract) and double combined treatment (amino acids+ seaweed extract) or (seaweed extract+ active yeast) registered better results of stem diameter, in both seasons. These above superior treatments increased such trait by 33.8, 28.3 and by $22.5 \%$ in the first seasons and by 34.5, 30.2 and by $25 \%$ in the second one over control for the two seasons, respectively.

The enhancement of stem diameter due to amino acids have been emphasized by Abd El-Azziz et al. (2010) on Thuja orientalis, Aly et al (2014) on Kapok seedlings, Al-Qubia (2012) on Helianthus annus and Mustafa and Ebeid (2013) on Albizza lebbekand and Taxodium distichum . 
Table (5): The influence of filter mud levels, amino acids, active yeast and seaweed extract on stem diameter (cm.) of khaya senegalensis seedlings during the two season of 2018 and 2019.

\begin{tabular}{|c|c|c|c|c|c|}
\hline \multicolumn{6}{|c|}{ First season } \\
\hline \multirow{2}{*}{$\begin{array}{c}\text { Simulant substances } \\
\text { treatment }(\mathrm{B})\end{array}$} & \multicolumn{4}{|c|}{ Filter mud g/seedling (A) } & \multirow{2}{*}{$\begin{array}{c}\text { Mean } \\
\text { (B) }\end{array}$} \\
\hline & $\mathbf{0}$ & 18 & 36 & 54 & \\
\hline Control & 1.36 & 1.41 & 1.48 & 1.53 & 1.45 \\
\hline Amino acids 100ppm & 1.40 & 1.42 & $\mathbf{1 . 5 0}$ & 1.52 & 1.46 \\
\hline Active yeast 5ml/L & 1.45 & 1.49 & $\mathbf{1 . 5 5}$ & 1.76 & 1.56 \\
\hline Seaweed 3m/L & 1.36 & 1.44 & 1.60 & 1.85 & 1.56 \\
\hline $\begin{array}{l}\text { Amino acids } \\
+ \text { Active yeast }\end{array}$ & 1.50 & 1.72 & 1.86 & 1.90 & 1.75 \\
\hline $\begin{array}{c}\text { Seaweed } \\
+ \text { Active yeast }\end{array}$ & 1.43 & 1.77 & 1.93 & 2.00 & 1.78 \\
\hline Amino acids + Seaweed & 1.68 & 1.83 & 1.90 & 2.03 & 1.86 \\
\hline $\begin{array}{c}\text { Am. acids + Ac.yeast + } \\
\text { Seaweed }\end{array}$ & 1.77 & 1.83 & 1.95 & 2.22 & 1.94 \\
\hline Mean (A) & 1.49 & 1.61 & 1.72 & 1.85 & \\
\hline L.S.D (0.05) & \multicolumn{2}{|c|}{$\mathrm{A}=\mathbf{0 . 0 5}$} & 0.17 & \multicolumn{2}{|c|}{$\mathrm{AB}=\mathbf{0 . 3 3}$} \\
\hline \multicolumn{6}{|c|}{$\begin{array}{ll}\text { Second season } \\
\end{array}$} \\
\hline \multirow{2}{*}{$\begin{array}{c}\text { Simulant substances } \\
\text { treatment }(\mathrm{B})\end{array}$} & \multicolumn{4}{|c|}{ Filter mud g/seedling (A) } & \multirow{2}{*}{$\begin{array}{c}\text { Mean } \\
(\mathbf{B})\end{array}$} \\
\hline & $\mathbf{0}$ & 18 & 36 & 54 & \\
\hline Control & 1.32 & 1.34 & 1.43 & 1.45 & 1.39 \\
\hline Amino acids 100ppm & 1.39 & 1.44 & 1.47 & 1.53 & 1.46 \\
\hline Active yeast $5 \mathrm{ml} / \mathrm{L}$ & 1.46 & 1.45 & 1.57 & 1.54 & 1.51 \\
\hline Seaweed 3m/L & 1.44 & 1.46 & 1.54 & 1.70 & 1.54 \\
\hline $\begin{array}{c}\text { Amino acids } \\
+ \text { Active yeast }\end{array}$ & 1.48 & 1.54 & 1.79 & 1.77 & 1.65 \\
\hline $\begin{array}{c}\text { Seaweed } \\
+ \text { Active yeast }\end{array}$ & 1.50 & 1.72 & 1.82 & 1.91 & 1.74 \\
\hline Amino acids + Seaweed & 1.64 & 1.70 & 1.86 & 2.05 & 1.81 \\
\hline $\begin{array}{l}\text { Am. acids + Ac.yeast + } \\
\text { Seaweed }\end{array}$ & 1.69 & 1.79 & 1.84 & 2.17 & 1.87 \\
\hline $\begin{array}{c}\text { Mean }(\mathrm{A}) \\
\end{array}$ & 1.49 & 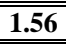 & 1.67 & 1.77 & \\
\hline L.S.D (0.05) & \multicolumn{2}{|c|}{$\mathbf{A}=\mathbf{0 . 0 8}$} & 0.16 & \multicolumn{2}{|c|}{$\mathrm{AB}=\mathbf{0 . 3 2}$} \\
\hline
\end{tabular}
lencucephala, Ahmed (2014) on Kapok seedlings, Hanafy et al .(2012) on Schefflera arbricola while Al- Hchami (2013) on peach transplants, Haggag et al. (2014) on olive seedlings, Al- Rawi et al. (2016) on Peach, Hamed (2017) on aniseand Farghaly (2018) on Kapok seedlings for seaweed extract.

According to the combined effect between the two studied factors, the listed data in table (5) cleared that is was statistically significant on stem diameter during the two consecutive seasons. The addition of most of combined treatments in both seasons, resulted a significant augment in such trait comparing to untreated plants. Obviously, the most effective treatments were obtained by applying either the high level of filter mud (54 g/seedling) and the moderate level 
of filter mud (36 g/seedling) in combination with (amino acids+ active yeast+ seaweed extract) or (amino acids+ seaweed extract) in comparison with those obtained by other combination treatments, during the two growing seasons.

Leaves dry weight/ seedling:

The obtained data in table (6) indicated that leaves dry weight/ seedling of khaya seedlings was significantly increased, in both seasons, due to applying organic manure as filter mud at all levels, comparing to the check treatment. Clearly, significant differences among all filter mud levels in both seasons, except for between the high and moderate levels in the first season were observed. Therefore, the use of filter mud at the moderate level in the first season gave the heaviest leaves dry weight reached 43.7 over untreated plants. While, in the second season the heaviest weight of such trait was noticed by applying the high level of filter mud as ranged $43.2 \%$ over control.

The increaments of leaves weight due to the application of organic manure have been reported by Ali et al (2001) and El-Sayed, and Abdou (2002) on khaya senegalansis, Abou - El-Makarem (2016) on moringa, Ali et al (2020) and Abd El-Raheem (2020) on Taxodium distichum seedling .

With respect to stimulant substance treatments, the registered results in table (6) indicated that spraying khaya seedlings with all the three studied substances, in both seasons, either alone or to together resulted a significant augment in leaves dry weight/ seedling as compared to no sprayed plants. Obviously, the heaviest leaves dry weight/ seedling was obtained as a result of adding the triple combined treatment (amino acids+ active yeast+ seaweed extract) reached 40.6 and $35.6 \%$ over control, during the two seasons, respectively.

The role of stimulant substances in augmenting leaves weight was also discussed by Talaat et al. (2005) on Catharanthus roseus, Abou Dahab and Abd EI - Aziz (2006) on Philodenvron erubescens, Shehata et al. (2011) on Celeriac, Mustafa and Ebeid (2013) on Albizza lebbekand and Taxodium distichum, Aly et al. (2014) on Kapok seedlings. Regarding to amino acids, Al-Qubia (2012) on roselle, ElSherbeny et al. (2007) on rue, Ahmed (2014) on Kapok seedlings and Ali et al. (2020,) on Taxodium distichum. Concerning to active yeast and Akila and Jeyadoss (2010) on Helianthus annus, Shhehata et al. (2011) on Apium graveolens, Ali et al. (2018) and Farghaly (2018) on Kapok seedlings for seaweed extract.

The interaction between the two examined factors on leaves dry weight/ seedlings of khaya had significant effect during the two experimental seasons (table 6). Such trait was significantly increased due to applying the most of combined treatments, during the two growing 
seasons. Apparently the use of filter mud at the high level (54 g/ seedling) with the triple combined treatment (amino acids+ active yeast+ seaweed extract) or (seaweed extract+ active yeast) or (amino acids+ seaweed extract) proved to be more effective in increasing leaves dry weight than those obtained by other combination treatments, during the two consecutive seasons.

Table (6): The influence of filter mud evel, amino acids, active yeast and seaweed extract on stem diameter (cm.) of khaya senegalensis seedlings during the two season of 2018 and 2019.

\begin{tabular}{|c|c|c|c|c|c|}
\hline \multicolumn{6}{|c|}{ First season } \\
\hline \multirow{2}{*}{$\begin{array}{c}\text { Simulant substances } \\
\text { treatment }(B)\end{array}$} & \multicolumn{4}{|c|}{ Filter mud g/seedling (A) } & \multirow{2}{*}{$\begin{array}{c}\text { Mean } \\
\text { (B) }\end{array}$} \\
\hline & $\mathbf{0}$ & 18 & 36 & 54 & \\
\hline Control & 35.0 & 45.5 & 48.4 & 51.1 & 45.0 \\
\hline Amino acids100ppm & 38.3 & 44.8 & 58.4 & 65.0 & 51.6 \\
\hline Active yeast $5 \mathrm{ml} / \mathrm{L}$ & 37.0 & 51.3 & 55.2 & 62.3 & 51.5 \\
\hline Seaweed 3m/L & 43.4 & 45.9 & 59.5 & 57.3 & 51.5 \\
\hline $\begin{array}{c}\text { Amino acids } \\
+ \text { Active yeast }\end{array}$ & 44.7 & 47.0 & 59.1 & 54.9 & 51.4 \\
\hline $\begin{array}{c}\text { Seaweed } \\
+ \text { Active yeast }\end{array}$ & 42.3 & 53.3 & 61.8 & 68.2 & 56.4 \\
\hline $\begin{array}{l}\text { Amino acids } \\
+ \text { Seaweed }\end{array}$ & 41.6 & 50.6 & 63.0 & 66.5 & 55.40 \\
\hline $\begin{array}{c}\text { Am. acids + Ac.yeast + } \\
\text { Seaweed }\end{array}$ & 45.3 & 62.9 & 66.0 & 78.9 & 63.3 \\
\hline Mean (A) & 41.0 & 50.2 & 58.9 & 63.0 & \\
\hline L.S.D (0.05) & \multicolumn{2}{|c|}{$\mathrm{A}=\mathbf{4 . 9}$} & $B=6.3$ & \multicolumn{2}{|c|}{$\mathrm{AB}=12.7$} \\
\hline \multicolumn{6}{|c|}{$\begin{aligned} \text { Second season } \\
\end{aligned}$} \\
\hline \multirow{2}{*}{$\begin{array}{c}\text { Simulant substances } \\
\text { treatment }(B)\end{array}$} & \multicolumn{4}{|c|}{ Filter mud g/seedling (A) } & \multirow{2}{*}{$\begin{array}{c}\text { Mean } \\
\text { (B) }\end{array}$} \\
\hline & $\mathbf{0}$ & 18 & 36 & 54 & \\
\hline Control & 33.0 & 40.5 & 4 & $\begin{array}{l}47.8 \\
\end{array}$ & 41.3 \\
\hline Amino acids 100ppm & 36.1 & 42.7 & 49.4 & 57.9 & 46.5 \\
\hline Active yeast 5ml/L & 37.9 & 48.6 & 53.6 & 57.3 & 49.3 \\
\hline Seaweed 3m/L & 41.2 & 44.7 & 58.3 & 55.9 & $\mathbf{5 0 . 0}$ \\
\hline $\begin{array}{l}\text { Amino acids } \\
+ \text { Active yeast }\end{array}$ & 43.7 & 46.8 & 56.7 & 56.1 & 50.8 \\
\hline $\begin{array}{c}\text { Seaweed } \\
+ \text { Active yeast }\end{array}$ & 40.9 & 50.2 & 55.4 & 60.8 & 51.8 \\
\hline $\begin{array}{c}\text { Amino acids } \\
+ \text { Seaweed }\end{array}$ & 43.5 & 47.5 & 55.6 & 58.0 & 51.1 \\
\hline $\begin{array}{c}\text { Am. acids + Ac.yeast } \\
\text { + Seaweed }\end{array}$ & 43.3 & 56.2 & 59.4 & 65.0 & 56.0 \\
\hline $\begin{array}{c}\text { Mean }(\mathrm{A}) \\
\end{array}$ & 40.0 & 47.2 & 54.0 & 57.3 & \\
\hline L.S.D (0.05) & \multicolumn{2}{|c|}{$\mathrm{A}=2.7$} & $B=4.9$ & \multicolumn{2}{|c|}{$\mathrm{AB}=9.7$} \\
\hline
\end{tabular}

\section{Stem dry weight/ seedling:}

Illustrated data in table (7) cleared that fertilizing khaya seedlings with organic manure as filter mud at all levels in both seasons ,caused a significant augment in stem dry weight/ seedling as compared to the check treatment. Apparently, the difference among all levels of filter mud 
were significant except for between the low and moderate levels in the second season. The use of the high level of filter mud $(54 \mathrm{~g} / \mathrm{seedling})$ gave the heaviest stem dry weight/ seedling reached 76.9 and $61.7 \%$ over control in the first and second seasons, respectively.

The positive effect of organic manure on stem weight was also revealed by Ali et al.(2001) and El-Sayed and Abdou (2002) on khaya senegalansis seedling, Ahmed et al (2006) on populous nigra and Ali et al.(2020) and Abd El-Raheem (2020) on Taxodium distichum seedling .

In connection, data in table (7) showed that stem dry weight/ seedling of khaya was significantly increased, during the two seasons, due to foliar spray with the combined treatments (amino acids+ active yeast + seaweed extract), (amino acids+ seaweed extract) and (seaweed extract+ active yeast), as well as, the single treatment (amino acids) in comparison with no sprayed ones. From the obtained results, it could be noticed that the utilization of the triple combined treatment (amino acids + active yeast+ seaweed extract). Proved to be more effective in increasing stem dry weight/ seedling, in both seasons, as compared to no sprayed plants. This superior previous treatment increased such trait by 60 and by $55 \%$ over check treatment, during the two experimental seasons, respectively.

The capability of the stimulant substances on enhancing stem weight was also insured by Talat $\boldsymbol{e t}$ al. (2005) on Catharanthus rosens, Abou Dahab and Abd El - Aziz (2006) on Philodendron erubescens, Mustafa and Ebeid (2013) on Albizza lebbekand and Taxodium distichum Aly et al. (2014) on Kapok seedlings for amino acids, Al-Qubaia (2002) on roselle, El-Sherbeny et al. (2007) on rue Ahmed (2014) on kapok concerning to active yeast, while Ali et al.(2018) and Farghaly (2018) on Kapok, AbdEl-Aziz et al.(2011) on Amaranthus triclor regarding to seaweed extract.

Table (7) emphasized that the combined effect between the two tested factors, in both seasons, had statistically significant on stem dry weight/ seedling of khaya. Clearly, the most of combined treatments, during the two growing seasons, resulted a significant augment in stem dry weight/ seedling as compared to untreated ones. The most effective treatments of such trait were detected when applying filter mud at the high level (54 g/ seedling) with the combined treatments (amino acids + active yeast + seaweed extract), (amino acids + seaweed extract) and (seaweed extract + active yeast), in addition to the moerrate level of filter mud (36 g/ seedling) plus the triple combined treatment (amino acids + active yeast + seaweed extract), in comparison with those obtained by other combination treatments, during the two experimental seasons. 
Table (7): The influence of filter mud levels, amino acids, active yeast and seaweed extract on stem dry weight of khaya senegalensis seedlings during the two season of 2018 and 2019.

\begin{tabular}{|c|c|c|c|c|c|}
\hline \multicolumn{6}{|c|}{ First season } \\
\hline \multirow{2}{*}{$\begin{array}{c}\text { Simulant substances } \\
\text { treatment }(\mathrm{B})\end{array}$} & \multicolumn{4}{|c|}{ Filter mud g/seedling (A) } & \multirow{2}{*}{$\begin{array}{c}\text { Mean } \\
\text { (B) }\end{array}$} \\
\hline & $\mathbf{0}$ & 18 & 36 & 54 & \\
\hline Control & 19.0 & 27.0 & 32.0 & 37.9 & 29.0 \\
\hline Amino acids 100ppm & 27.9 & 33.0 & 38.9 & 46.0 & 36.5 \\
\hline Active yeast $5 \mathrm{ml} / \mathrm{L}$ & 27.7 & 31.3 & 35.9 & 39.5 & 33.6 \\
\hline Seaweed 3m/L & 21.0 & 23.8 & 33.7 & 40.9 & 29.9 \\
\hline $\begin{array}{c}\text { Amino acids } \\
+ \text { Active yeast }\end{array}$ & 23.7 & 32.7 & 39.4 & 42.3 & 34.5 \\
\hline $\begin{array}{c}\text { Seaweed } \\
+ \text { Active yeast }\end{array}$ & 27.0 & 34.7 & 44.8 & 50.6 & 39.3 \\
\hline $\begin{array}{c}\text { Amino acids } \\
+ \text { Seaweed }\end{array}$ & 28.7 & 39.3 & 42.6 & 50.6 & 40.3 \\
\hline $\begin{array}{c}\text { Am. acids + Ac.yeast + } \\
\text { Seaweed }\end{array}$ & 33.7 & 43.0 & 49.4 & 59.9 & 46.5 \\
\hline Mean (A) & 26.0 & 33.1 & 39.6 & 46.0 & \\
\hline L.S.D (0.05) & \multicolumn{2}{|c|}{\begin{tabular}{l|l}
$\mathrm{A}=4.9$ & \\
\end{tabular}} & $B=6.2$ & \multicolumn{2}{|c|}{$\mathrm{AB}=12.4$} \\
\hline \multicolumn{6}{|c|}{$\begin{array}{ll}\text { Second season } \\
\end{array}$} \\
\hline \multirow{2}{*}{$\begin{array}{c}\text { Simulant substances } \\
\text { treatment }(\mathbf{B})\end{array}$} & \multicolumn{4}{|c|}{ Filter mud g/seedling (A) } & \multirow{2}{*}{$\begin{array}{c}\text { Mean } \\
\text { (B) }\end{array}$} \\
\hline & $\mathbf{0}$ & 18 & 36 & 54 & \\
\hline Control & 20.1 & 25.8 & 33.0 & 34.2 & 28.3 \\
\hline Amino acids 100ppm & 26.9 & 29.8 & 34.2 & 48.6 & 34.9 \\
\hline Active yeast $5 \mathrm{ml} / \mathrm{L}$ & 25.0 & 31.1 & 33.2 & 36.0 & 31.3 \\
\hline Seaweed 3m/L & 23.0 & 27.3 & 29.6 & 35.7 & 28.9 \\
\hline $\begin{array}{l}\text { Amino acids } \\
+ \text { Active yeast }\end{array}$ & 24.1 & 30.4 & 33.6 & 40.3 & 32.1 \\
\hline $\begin{array}{c}\text { Seaweed } \\
+ \text { Active yeast }\end{array}$ & 27.0 & 32.5 & 39.2 & 46.9 & 36.4 \\
\hline $\begin{array}{c}\text { Amino acids } \\
+ \text { Seaweed }\end{array}$ & 29.0 & 36.4 & 40.9 & 43.9 & 37.6 \\
\hline $\begin{array}{l}\text { Am. acids + Ac.yeast + } \\
\text { Seaweed }\end{array}$ & 33.9 & 45.0 & 44.6 & 52.2 & 43.9 \\
\hline $\begin{array}{c}\text { Mean }(A) \\
\end{array}$ & 26.1 & 32.7 & 36.0 & 42.2 & \\
\hline L.S.D (0.05) & \multicolumn{2}{|c|}{$A=5.9$} & $\mathrm{~B}=5.6$ & \multicolumn{2}{|c|}{$\mathrm{AB}=11.3$} \\
\hline
\end{tabular}

Nitrogen, phosphorus and potassium percentages:

The obtained results in Tables $(\mathbf{8 , 9}$ and 10) Revealed that supplying Khaya seedlings with organic manure as filter mud at all levels, during the two experimental seasons, led to a significant increase in the three examined elements $(\mathrm{N}, \mathrm{P}$ and $\mathrm{K} \%)$ in the leaves, except for the low level of filter mud (18 g/ seedling) regarding $\mathrm{N} \%$ in the first season and $\mathrm{P}$ and $\mathrm{K} \%$ for the two seasons, as well as, the moderate level (36 g/ seedling) concerning $\mathrm{K} \%$ in the second one, as compared to unfertilized ones. As for $\mathrm{N} \%$, significant differences among all levels of filter mud in the second season, were detected. On the other hand, the difference among all levels of filter mud were no significant in the first one. Regarding P\%, significant differences among all levels of filter mud, 
in both seasons were observed, except for between the moderate and high levels, in the first season. conserving $\mathrm{K} \%$, no significant difference among all levels of filter mud, in the two seasons, were noticed, except for between the low and high levels in the first season. The highest values of $\mathrm{N}, \mathrm{P}$ and $\mathrm{K} \%$ were given by applying the high level of filter mud (54 g/ seedling) as ranged 11.2 And $8.4 \%$ for N\%, 12.6 and $17.5 \%$ for $\mathrm{P} \%$ and 6 and $5 \%$ for $\mathrm{K} \%$ over control, in both seasons, respectively.

The promoting effect of organic manure on $\mathrm{N}, \mathrm{P}$ and $\mathrm{K}$ was also. studied by Ali et al. (2001) and El-Sayed and Abdou (2002) on khaya senegalansis, Ahmed et al. (2006) on populous nigra and populous alba and Mahmmoud (2014) on populous nigra, Ali et al. (2020) and Abd El-Raheem (2020) on Taxodium distichum seedling .

Regarding stimulant substance treatments, data in Tables $\mathbf{( 8 , 9}$ and 10) indicated that spraying Khaya seedlings with the examined substances either alone or mixed, in both seasons, caused a significant augment in N\%, except for amino acids treatment in the two seasons and seaweed extract treatment in the second one, comparing to untreated ones. With regard to $\mathrm{P} \%$, it was significantly increased, in both seasons, duo to using the combined stimulant substances, except for the treatment of amino acids + active yeast, in the first season, as compared to no sprayed plants. Concerning K\% foliar spray with the examined stimulant substances either single or together resulted a significant augment in such trait, in the two seasons, as compared to control, except for amino acids treatment in both seasons and active yeast treatment in the second one. Clearly, the use of triple combined treatment (amino acids + active yeast + seaweed extract) and double combined treatment (amino acids + seaweed extract) gave the highest values of the three studied elements. $\mathrm{N}$, $\mathrm{P}$ and $\mathrm{K} \%$ as compared to other treatments, during the two experimental seasons. Numerically, these previous superior treatments increased $\mathrm{N} \%$ by $11.9,12.2,9.6$, And by $8.4 \%$, by $15.3,10.8,22$ and by $15.7 \%$ for P\% and by $10.6,9.1,11.8$ and by $8.6 \%$ for $\mathrm{K} \%$ over no sprayed ones, during the two consecutive seasons, respectively.

The role of amino acids in enhancing the elements of $\mathrm{N}, \mathrm{P}$ and $\mathrm{K}$ was also insured by Abd El-Azziz et al.(2010) on Thuja orientalis, Ali and Hassan (2013) on Tagetes eracta Abd El-Rahman et al. (2008) on fennel. Abd-Rahman et al. (2016) on Chamomil. Concerning active yeast, meanwhile, Ahmed (2002) on Leucaena leucoceohala, Moustafa and El-Hosseiny (2001) on Washington Navel orange, Shoug (2019) on Balady mandarin trees, Saoir and Archer (2010) on apple seedlings, Shehata et al (2011) on Apium graveolens, Al-Hadethi (2015) on apricot trees, Hassan (2015) on dill, Al- Rawi et al (2016) on peach Hamed (2017) on anise and Ali et al. (2018) and Fargaly (2018) on Kapok seedling, Regarding seaweed extract. 
In connection, the interaction effect between the two studied factors was statistically significant on $\mathrm{N}, \mathrm{P}$ and $\mathrm{K} \%$ in the leaves of Khaya seedlings, during the two experimental seasons. Clearly, the use of most of combined treatments, in both seasons, resulted a significant increase in $\mathrm{N}, \mathrm{P}$ and $\mathrm{K} \%$ comparing to untreated ones. Apparently, the highest values of $\mathrm{N}, \mathrm{P}$ and $\mathrm{K} \%$ were given by receiving Khaya seedlings the high level of filter mud (54g / seedling) and the moderate one $(36 \mathrm{~g} /$ seedling) in combination with the triple combined treatment (amino acid + active yeast + seaweed extract) plus the double combined treatment (amino acids + seaweed extract), mostly, in comparison with those obtained by other combination treatments during the two experimental seasons, as clearly shown in Tables $(8,9$ and 10).

Table (8): The influence of filter mud levels, amino acids, active yeast and seaweed extract on $\mathrm{N} \%$ of khaya senegalensis seedlings during the two season of 2018 and 2019.

\begin{tabular}{|c|c|c|c|c|c|}
\hline \multicolumn{6}{|c|}{ First season } \\
\hline \multirow{2}{*}{$\begin{array}{c}\text { Simulant substances } \\
\text { treatment }(B)\end{array}$} & \multicolumn{4}{|c|}{ Filter mud g/seedling (A) } & \multirow{2}{*}{$\begin{array}{c}\text { Mean } \\
\text { (B) }\end{array}$} \\
\hline & $\mathbf{0}$ & 18 & 36 & 54 & \\
\hline Control & 3.25 & $\overline{\overline{3.30}}$ & 3.33 & 3.50 & 3.35 \\
\hline Amino acids 100ppm & 3.33 & 3.35 & 3.60 & 3.58 & 3.47 \\
\hline Active yeast $5 \mathrm{ml} / \mathrm{L}$ & 3.37 & 3.59 & 3.78 & 3.80 & 3.64 \\
\hline Seaweed 3m/L & 3.26 & 3.51 & 3.79 & 3.83 & 3.60 \\
\hline $\begin{array}{c}\text { Amino acids } \\
+ \text { Active yeast }\end{array}$ & 3.39 & 3.60 & 3.58 & 3.81 & 3.60 \\
\hline $\begin{array}{c}\text { Seaweed } \\
+ \text { Active yeast } \\
\end{array}$ & 3.42 & 3.70 & 3.72 & 3.64 & 3.62 \\
\hline $\begin{array}{c}\text { Amino acids } \\
+ \text { Seaweed }\end{array}$ & 3.48 & 3.78 & 3.85 & 3.92 & 3.76 \\
\hline $\begin{array}{l}\text { Am. acids + Ac.yeast + } \\
\text { Seaweed }\end{array}$ & 3.57 & 3.55 & 3.90 & 3.96 & 3.75 \\
\hline $\begin{array}{c}\text { Mean }(\mathrm{A}) \\
\end{array}$ & 3.38 & 3.55 & 3.69 & 3.76 & \\
\hline "L.S.D (0.05) & \multicolumn{2}{|c|}{$\mathrm{A}=0.18$} & $\overline{\mathbf{B}=0.15}$ & \multicolumn{2}{|c|}{$\overline{\mathrm{AB}}=\mathbf{0 . 3 0}$} \\
\hline \multicolumn{6}{|c|}{ Second season } \\
\hline \multirow{2}{*}{$\begin{array}{l}\text { Simulant substances } \\
\text { treatment }(B)\end{array}$} & \multicolumn{4}{|c|}{ Filter mud g/seedling (A) } & \multirow{2}{*}{$\underset{(\text { B })}{\text { Mean }}$} \\
\hline & $\mathbf{0}$ & 18 & 36 & 54 & \\
\hline Control & 3.34 & $\overline{\mathbf{3 . 3 6}}$ & 3.50 & 3.56 & $\overline{3.44}$ \\
\hline Amino acids 100ppm & 3.32 & 3.40 & 3.46 & 3.55 & 3.43 \\
\hline Active yeast $5 \mathrm{ml} / \mathrm{L}$ & 3.30 & 3.53 & 3.65 & 3.75 & 3.56 \\
\hline Seaweed 3m/L & 3.30 & 3.40 & 3.56 & 3.70 & 3.49 \\
\hline $\begin{array}{c}\text { Amino acids } \\
+ \text { Active yeast }\end{array}$ & 3.43 & 3.57 & 3.62 & 3.79 & 3.60 \\
\hline $\begin{array}{c}\text { Seaweed } \\
+ \text { Active yeast }\end{array}$ & 3.54 & 3.68 & 3.71 & 3.75 & 3.67 \\
\hline $\begin{array}{c}\text { Amino acids } \\
+ \text { Seaweed }\end{array}$ & 3.63 & 3.72 & 3.74 & 3.84 & 3.73 \\
\hline $\begin{array}{l}\text { Am. acids + Ac.yeast + } \\
\text { Seaweed }\end{array}$ & 3.65 & 3.70 & 3.80 & 3.92 & 3.77 \\
\hline Mean $(\mathbf{A})$ & 3.44 & $\overline{\overline{3.55}}$ & 3.63 & 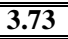 & \\
\hline L.S.D (0.05) & \multicolumn{2}{|c|}{$\mathrm{A}=\mathbf{0 . 0 7}$} & $\mathbf{B = 0 . 1 2}$ & \multicolumn{2}{|c|}{$\overline{\mathrm{AB}}=\mathbf{0 . 2 3}$} \\
\hline
\end{tabular}


Egypt. J. of Appl. Sci., 35 (12) 2020

Table (9): The influence of filter mud levels, amino acids, active yeast and seaweed extract on $p \%$ of khaya senegalensis seedlings during the two season of 2018 and 2019.

\begin{tabular}{|c|c|c|c|c|c|}
\hline \multicolumn{6}{|c|}{ First season } \\
\hline \multirow{2}{*}{$\begin{array}{l}\text { Simulant substances } \\
\text { treatment }(B)\end{array}$} & \multicolumn{4}{|c|}{ Filter mud g/seedling (A) } & \multirow{2}{*}{$\begin{array}{c}\text { Mean } \\
\text { (B) }\end{array}$} \\
\hline & $\mathbf{0}$ & 18 & 36 & 54 & \\
\hline Control & 0.292 & 0.300 & 0.366 & 0.375 & 0.333 \\
\hline Amino acids 100ppm & 0.308 & 0.302 & 0.359 & 0.370 & 0.335 \\
\hline Active yeast $5 \mathrm{ml} / \mathrm{L}$ & 0.328 & 0.340 & 0.365 & 0.376 & 0.352 \\
\hline Seaweed 3m/L & 0.331 & 0.335 & 0.355 & 0.380 & 0.350 \\
\hline $\begin{array}{l}\text { Amino acids } \\
+ \text { Active yeast }\end{array}$ & 0.337 & 0.333 & 0.362 & 0.360 & 0.348 \\
\hline $\begin{array}{c}\text { Seaweed } \\
+ \text { Active yeast }\end{array}$ & 0.346 & 0.353 & 0.351 & 0.367 & 0.354 \\
\hline $\begin{array}{l}\text { Amino acids } \\
\text { + Seaweed }\end{array}$ & 0.359 & 0.368 & 0.364 & 0.384 & 0.369 \\
\hline $\begin{array}{l}\text { Am. acids + Ac.yeast + } \\
\text { Seaweed }\end{array}$ & 0.374 & 0.381 & 0.385 & 0.397 & 0.384 \\
\hline Mean (A) & 0.334 & 0.339 & 0.363 & 0.376 & \\
\hline L.S.D (0.05) & \multicolumn{2}{|c|}{$A=0.020$} & \multicolumn{2}{|c|}{$B=0.019$} & $\mathrm{AB}=\mathbf{0 . 0 3 8}$ \\
\hline \multicolumn{6}{|c|}{ Second season } \\
\hline \multirow{2}{*}{$\begin{array}{l}\text { Simulant substances } \\
\text { treatment }(B)\end{array}$} & \multicolumn{4}{|c|}{ Filter mud g/seedling (A) } & \multirow{2}{*}{$\begin{array}{c}\text { Mean } \\
\text { (B) }\end{array}$} \\
\hline & $\mathbf{0}$ & 18 & 36 & 54 & \\
\hline Control & 0.265 & 0.282 & 0.322 & 0.326 & 0.299 \\
\hline Amino acids 100ppm & 0.277 & 0.287 & 0.317 & 0.315 & 0.299 \\
\hline Active yeast $5 \mathrm{ml} / \mathrm{L}$ & 0.275 & 0.281 & 0.313 & 0.336 & 0.301 \\
\hline Seaweed $3 \mathrm{~m} / \mathrm{L}$ & 0.295 & 0.304 & 0.322 & 0.354 & 0.319 \\
\hline $\begin{array}{l}\text { Amino acids } \\
+ \text { Active yeast }\end{array}$ & 0.293 & 0.300 & 0.342 & 0.350 & 0.321 \\
\hline $\begin{array}{c}\text { Seaweed } \\
+ \text { Active yeast }\end{array}$ & 0.310 & 0.308 & 0.350 & 0.362 & 0.333 \\
\hline $\begin{array}{l}\text { Amino acids } \\
+ \text { Seaweed }\end{array}$ & 0.315 & 0.335 & 0.365 & 0.370 & 0.346 \\
\hline $\begin{array}{l}\text { Am. acids + Ac.yeast + } \\
\text { Seaweed }\end{array}$ & 0.348 & 0.359 & 0.373 & 0.380 & 0.365 \\
\hline Mean (A) & 0.297 & 0.307 & 0.338 & 0.349 & \\
\hline L.S.D (0.05) & \multicolumn{2}{|c|}{$A=0.011$} & $B=0.022$ & \multicolumn{2}{|c|}{$A B=0.044$} \\
\hline
\end{tabular}


Table (10): The influence of filter mud levels, amino acids, active yeast and seaweed extract on $k \%$ of khaya senegalensis seedlings during the two seasons of 2018 and 2019.

\begin{tabular}{|c|c|c|c|c|c|}
\hline \multicolumn{6}{|c|}{ First season } \\
\hline \multirow{2}{*}{$\begin{array}{c}\text { Simulant substances } \\
\text { treatment }(B)\end{array}$} & \multicolumn{4}{|c|}{ Filter mud g/seedling (A) } & \multirow{2}{*}{$\begin{array}{c}\text { Mean } \\
(\mathbf{B})\end{array}$} \\
\hline & $\mathbf{0}$ & 18 & 36 & 54 & \\
\hline Control & 2.00 & 2.10 & 2.12 & 2.10 & 2.08 \\
\hline Amino acids 100ppm & 2.11 & 2.15 & 2.13 & 2.17 & 2.14 \\
\hline Active yeast $5 \mathrm{ml} / \mathrm{L}$ & 2.14 & 2.17 & 2.21 & 2.26 & 2.20 \\
\hline Seaweed 3m/L & 2.19 & 2.17 & 2.23 & 2.21 & 2.20 \\
\hline $\begin{array}{c}\text { Amino acids } \\
+ \text { Active yeast }\end{array}$ & 2.15 & 2.21 & 2.23 & 2.32 & 2.23 \\
\hline $\begin{array}{c}\text { Seaweed } \\
+ \text { Active yeast }\end{array}$ & 2.13 & 2.18 & 2.26 & 2.30 & 2.22 \\
\hline $\begin{array}{l}\text { Amino acids } \\
+ \text { Seaweed }\end{array}$ & 2.20 & 2.25 & 2.28 & 2.35 & 2.27 \\
\hline $\begin{array}{c}\text { Am. acids + } \\
\text { Ac.yeast + Seaweed }\end{array}$ & 2.18 & 2.26 & 2.33 & 2.42 & 2.30 \\
\hline Mean (A) & 2.14 & 2.19 & 2.22 & 2.27 & \\
\hline L.S.D (0.05) & \multicolumn{2}{|c|}{$\mathrm{A}=\mathbf{0 . 0 8}$} & 0.08 & \multicolumn{2}{|c|}{$\mathrm{AB}=\mathbf{0 . 1 7}$} \\
\hline \multicolumn{6}{|c|}{ Second season } \\
\hline \multirow{2}{*}{$\begin{array}{c}\text { Simulant substances } \\
\text { treatment }(\text { B })\end{array}$} & \multicolumn{4}{|c|}{ Filter mud g/seedling (A) } & \multirow{2}{*}{$\begin{array}{c}\text { Mean } \\
\text { (B) }\end{array}$} \\
\hline & $\mathbf{0}$ & 18 & 36 & 54 & \\
\hline Control & 2.15 & 2.18 & 2.23 & 2.27 & 2.21 \\
\hline Amino acids 100ppm & 2.22 & 2.20 & 2.23 & 2.32 & 2.24 \\
\hline Active yeast $5 \mathrm{ml} / \mathrm{L}$ & 2.23 & 2.28 & 2.29 & 2.26 & 2.27 \\
\hline Seaweed 3m/L & 2.30 & 2.33 & 2.35 & 2.36 & 2.34 \\
\hline $\begin{array}{l}\text { Amino acids } \\
+ \text { Active yeast }\end{array}$ & 2.32 & 2.35 & 2.33 & 2.37 & 2.34 \\
\hline $\begin{array}{c}\text { Seaweed } \\
+ \text { Active yeast }\end{array}$ & 2.28 & 2.34 & 2.36 & 2.35 & 2.33 \\
\hline $\begin{array}{l}\text { Amino acids } \\
+ \text { Seaweed }\end{array}$ & 2.31 & 2.39 & 2.43 & 2.46 & 2.40 \\
\hline $\begin{array}{c}\text { Am. acids + } \\
\text { Ac.yeast }+ \text { Seaweed } \\
\end{array}$ & 2.35 & 2.40 & 2.51 & 2.63 & 2.47 \\
\hline Mean (A) & 2.27 & 2.31 & 2.34 & 2.38 & \\
\hline L.S.D (0.05) & \multicolumn{2}{|c|}{$A=0.09$} & 0.09 & \multicolumn{2}{|c|}{$\mathrm{AB}=0.18$} \\
\hline
\end{tabular}

From the obtained results, it could be discussed as follows: the enhancement in plant growth parameters (stem length, stem diameter, leaves dry weight / seedling and stem dry weight / seedling, as well as, N, $\mathrm{P}$ and $\mathrm{K} \%$ due to fertilizing Khaya seedlings with filter mud as organic manure reflected the positive, biological and physiological roles of organic manures which were explored by many investigators such as, Bohn et al. (1985) emphasized that organic matter as a main source of the elements, N, P and S, as well as, contains high content of B and Mo, and bisedes to considered as a source of energy for Azotobacter growth. the use of organic manure minimized nutrients lost by leaching (Saber, 1997).Also, organic manure increased microbial activities in the root 
zone by using it to the soil (Taiwo, et al., 2002). Furthermore, Natarajan (2007) and Sreenivasa et al. (2010) claimed the organic manures contain growth promoting hormones (IAA and GA), macronutrients, essential micronutrients and beneficial microorganisms. the positive effect of amino acids on improving the studied traits due to the physiological and biological roles of amino acids which were explained by many authors such as, Kamar and Omar (1987) mentioned that amino acids play physiological roles for examples: biosynthesis of enzymes, coenzymes, purine and pyrimidine basis, vitamins, pigments, terpenoids and alkaloids. They are precursors or activators of phytohormones and growth substances. Kowalczyk and Zielony (2008) proved that amino acids capable enhancing plant growth, yield and mitigates the injuries by a biotic stress. Moreover, utilizing amino acids on many plants grown under low fertile soils resulted an enhancement in growth of these plants (Tantawy et al.2009 and Abd El-Mawgoud et al., 2011). The increments in plant growth characteristics and $\mathrm{N}, \mathrm{P}$ and $\mathrm{K} \%$ due to foliar spray with active yeast could be attributed to the biological and physiological roles of active yeast which were discussed by some authors such as, Tarrow and Nakase (1975), and Subba Rao (1984) pointed that active dry yeast contains high amounts of four vitamins, especially vitamin B which plays an important role in improving the plant growth and controlling the incidence of fungi diseases.

Nagodawithana (1991) reported that active dry yeast is considered as a good source of many natural growth substances i. e. cytokinins, a lot of vitamins, Most nutritional elements namely $\mathrm{P}, \mathrm{K}, \mathrm{S}$, $\mathrm{Ca}, \mathrm{Na}$, and $\mathrm{Mg}$ and also, organic compounds (nucleic acids, proteins, lipids and carbohydrates). The enhancement in parameters studied of this study as a result of applying seaweed extract might be attributed to the positive, physiological and biological roles of seaweed extract which were explained by several authors such as, Adam (1999) showed that seaweed extract contains phytohormones (IAA, GA and cytokinins). It is an excellent natural fertilizer and as a source of organic matter. It contains higher amounts of elements namely, $\mathrm{N}, \mathrm{P}, \mathrm{K}, \mathrm{S}, \mathrm{Ca}, \mathrm{Mg}, \mathrm{Zn}$, $\mathrm{Mn}, \mathrm{Fe}$, and $\mathrm{C}$ (Tung et al. 2003). It is a good source of bioactive compounds such as, vitamins, protein, mineral carotenoids, essential fatty acids and dietary fiber (Osman and Salem, 2011). Pramanick et al. (2013) verified that seaweed extract improved various plant growth parameters and development due to good health around the plants. From the obtained results, it could be recommended to supply the soil of khaya 
senegalensis seedlings with filter mud at $54 \mathrm{~g} /$ seedling and foliar spray with amino acids (tryptophan and methionine) at $100 \mathrm{ppm}$, active yeast at $5 \mathrm{~g} / \mathrm{l}$ and seaweed extract at $3 \mathrm{ml} / \mathrm{l}$ to enhancing the growth and some chemical constituents traits under the investigation conditions.

\section{REFERENCE}

Abd El- Aziz, N. G. ; A. A. Maher, and M. M. Farahat (2010): Response of vegetative growth and some chemical constituents of thuia orientalis, L. Plant to foliar application of amino acids at Nubaria Journal of American science, 6 (3): 295- 301.

Abd El -Aziz, N.G. ; M.H. Mahgoub and H.S. Siam (2011):Growth, flowering and chemical constituents performance of Amaranthus tricolor plants as influenced by seaweed (Aschophyllum nodosum) extract application under salt stress condition. J. of Applied Sci. Res., 7:1472-1484.

Abd El- Mawgoud, A.M.R. ; A.M. El- Bassiouny ; A. Ghonam and S.D. Abou-Hussein (2011): Foliar application of amino acids and micronutrients enhance performance of green bean crop under newly reclaimed land conditions - Aust. J. Basic. Appl. Sci., 5 (6): 51- 55.

Abd El- Rahman, S. S. A. ; M. A. Faragallah and A. A. S. Abdel- Kader (2008): Growth, Yield and chemical composition of foeniculum vulgare, mill as affected by nitrogen, dry yeast and tryptophan application. Assiut. J. of Agric. Sci., 39 (3): 115- 134.

Abd El-Raheem, A.Sh. (2020): Response of Taxodium tree to some agricultural treatments Ph.D. Thesis, Fac. Agric., Al-Azhar Univ., Assiut.

Abd El-Rahman, A. J. (2016): Possibility of improving the productivity of Matric aria chamomilla plants by using some agriculrural treatments. M.Sc. thesis, Fac. Of Agric. Al-Azhar, Univ. Assiut.

Abdel-Aal, A.M.K. ; F.F. Ahmad and K.M. Hassan (2012). Partial replacement of chemical N Fertilizer in Balady mandarin Orchard though Application of Extracts of yeast, seaweed and farmyand manure - Minia J. Agric. Res \& Develop., 50 (1): 129-148.

Abdullatif, M.M. (2019): Enhancing the growth, yield and active ingredient of Coriander plants by using organic fertilization and some amino acids and vitamins. M. Sc. Thesis, Fac. Agric., Al-Azhar Univ., Assiut.

Abou Dahab, T.A.M. and H.G. Abd El -Azizz (2006): physiological effect of Diphenylamine and tryptophan on the growth and chemical constituents of philodendron erubescens plants. World $\mathbf{J}$ .Agric.Sci.,75:75-81. 
Abou El-Makarem, S. H. E. (2016), Response of moringa plants to some agricultural treatments, Ph.D. Dissertation, Faculty of Agriculture, Minia University, Egypt.

Adam, M.S. (1999). Promotive effect of cyanobacterin Nostoc Muscorum on the growth of some crop plants. Acta Microbiologioolinica, 48 (2): 163-171.

Ahmed, A.A. (2002), "study the effect of addition methods and concentration of active dry yeast on the growth and chemical composition of Leucaena Leucocephala", Proceedings of minia 1st conference of agriculture and Environmental science, Minia, Egypt

Ahmed, A. A. (2002), "Study the effect of addition methods and concentration of active dry yeast on the growth and chemical composition of Leucaena leucocephala", Proceedings of Minia 1 Conference for Agriculture and Environmental Science, Minia,

Ahmed, A.A.; A.F. Ali and R.A. Taha (2006): A comparative study between two popular species grown in sandy calcareous soils using certain compost levels. Minia J. Agric. Res. \& Develop. 26 (4): 663-681.

Ahmed, F. F. ; A. M. Akl ; F. M. El- Morsy and M. A. Ragab (1997), "the beneficial effect of bio-fertilizer on red roomy grape vines (Vitis vinfera, L.): 1- the effect on growth and vin nutritional statues", Annals of Agric science. Moshtohor, 35(1); 489- 495.

Ahmed, F.F.; A.A. Gobara ; E.E. Abo El- Komsan and A.F. Gamal (2008). Growth and fruiting of Washington Navel orange trees as affected by some antioxidant and algae extract treatments. Inter. Conf. For Environ. Studies Monufia Univ., pp. 200-220.

Ahmed, I.U. ; R. Saquib ; M. Qasim ; M. Saleem ; A.S. Khan and M. Yaseen, (2013). Humic acid and cultivar effects on growth yield, vase life, and corn characteristic of gladiolus. Chilean Journal of Agric. Res., 73 (4) Oct-Dec. 2013.

Ahmed, R. F. (2014), Effect of some growth media, bio-fertilization and antioxidants on ceiba penlandra, L. tree seedings, $\mathrm{Ph}$. D. Thesis, Faculty of Agriculture, Minya Univ.

Ahmed. M. ; E.A. Shalaby and N.T. Shanan (2011): the use of organic and inorganic culture in improving vegetative growth yield in characters and autioxidant activity of roselle plants (Hibiscus Sabdariffa;L) .African J. of Biotechnology .10(11):1988-1996.

Akila, N. and T. Jeyadoos (2010): The potential of seaweed liquid fertilizer on the growth and antioxidant enhancement of Helianthus annuus L. Oriental Journal of Chemistry, 26 (4): 1353-1360.

Akl, A. M. ; F.F. Ahmed ; F.M. El- Morsey and M.A. Ragab (1997),"the benefical effect of bio - fertilizer on Red Romy grape vine (Vitis 
vinifera L.):2-The effect on berrers"Annals of Agricultural Science Moshtohor Journal, 45 (1):497-502.

Al- Hchami, S.H.J. (2013). Effect of $\mathrm{Co}_{2}$ enrichment and foliar spray agro leaf and seaweed extract kelpak on growth of Nectarine transplant cv. Nectared 6. Ph.D. Dissertation, coll. of Agric., Univ. of Baghdad, pp.119.

Al- Qubia, A.I.(2012): Response of sunflower cultivar Giza-102 (Helianthus annus,L.) plants to spraying some antioxidants. Nature and science 10 (11) 11:1-6.

Al Rawi, W.A.A.; M.E.A. Al-Hadethi and A.A. Abdul- Kareem (2016). Effect of foliar application of Gibberellic acid and seaweed extract spray on growth and leaf mineral content on peach trees.The Iraqi Journal of Agricultral Sciences,47:(special Issue):98-105,2016.

Al-Hadethi, M.E.A. (2015). Effect of different fertilization sources and the growth regulator (Brassinosteroids) on growth and yield of Apricot trees. Ph.D.Dissertation, coll.Of Agric.,Univ.of Baghdad,pp.153.

Ali, A. F. (2001) Response of pot marlgold (Calendula officinalis, L.) plant to some rock phosphate sources and yeast, the fifth Arabian Horticulture conference, Ismailia, Egypt, PP. 30- 42.

Ali, A.F. and F.A.S. Hassan (2013): Impact of Foliar Application of Commercial Amino Acids Nutrition On The Growth And flowering of Tagetes Erecta .L.plant .J.of Apple . Sci. Res, 9 (1): :652-657.

Ali, A.F. ; N.A. Azzaz and E.A. Hassan (2006): Influence of spraying active yeast, methionine and ascorbic acids on growth, yield and oil of anise (Pimpinella anisum,L.) Plants . Minia J,Agric .Res. \&Dev .26(4):683-716.

Ali, A.F. ; A.A. Ahmed and M.M. El-Morshedy (2001) : Effect of some organic manure on vegetative growth and chemical composition of Khaya senegalensis. A. juss seedlings grown in different soil types. The fifth Arabia Hort. Conf. Ismailia, Egypt, 22 (2A): 377392.

Ali, A.F. ; E.A. Hassan ; E.H. Hamed and A.H. Abd El-Rahman (2016): Possibility of Enhancing Growth productivity of chamomilla plant by utilizing effective microorganisms, thiamine and some amino acids. j.boil . chem. Environ Sci.,11(1): 363-388

Ali, A.F. ; E.H. Hamad and M.H. Hemdan (2017): Study the possibility of enhancing the growth, yield and essential oil of anise plant by using some organic fertilization and natural substance treatments. J. Biol. Chem. Environ. Sci., 12 (2): 487-506.

Ali, A.F. ; M.K.A. Aly and M.M. Farghaly (2018): Response of Kapok seedlings to humic acid, seaweed extract and selenium treatments. J. Biol. Chem. Enviro., Sci., 13 (2): 237-260 
Ali, A.F. ; E.H. Amer and M.M. Abdullatif (2019): Study of growth, yield and chemical constituents of Coriander plants as affected by using organic fertilizations, and some natural substances. J. Biol., Chem. Enviro. Sci., 14

Ali, A.F.; A.A. Ahmed and A. Sh. Abd El-Raheem (2020): Influence of organic manure Minia Azotein, mycorrhizae fungi and active yeast application on growth and chemical constituents of Taxodium distichum seedling. Achives of Agriculture Sciences Journal, 3 (1): $1-23$.

Al-Qubaie, A.H. (2002) Effect of fertilization with potassium and bio fertilization with yeast on the tolerance of Hibiscus sabdariffa L. plants to irrigation with saline water J.Agric Sci., Mansoura Univ., 27 (9): 6111-6122.

Attoa, G.E. ; H.E. Wahba and A.A. Farahat (2002): Effect of some amino acids and sulphur fertilization on growth and chemical composition of Iberis amara, L. plant . Egypt . J. Hort., 29:17-37.

Badarn, O.A. ; E.F. Kandeel ; M.H. El-Lakkany ; T.A. Omran ; M. L. El-Osta and A.C. Badr El-Din (1978). Practical Principles of timbre trees ans woods technology science. Dar El-kotob ElGamieiah, Alexandria, Egypt

Black, C.A. ; D.D. Evans ; L.E. Ersminger ; J.L. White and F.E. Clarc (1965) Methods of Soils Analysis. Am.Soc.Agron.Inc. Bull. Madison, Wisconsin, M.S.A.P,891-1440.

Bohn, H.L. ; B.L. Meneal and G.A.O. Connor (1985), soil chemistry 2nd ed., A Wiley Interscience publication john Wiley and sons, New york, U.S.A.

Chapman, H.D. and P.F. Pratt (1975). Methods of analysis for soils, plants and water, California Univ. Division of Agric. Sci., 172-173.

Chapman, V. J. and D. J. Chapman (1980). Seaweed and their uses, third edition public, chapman and Hall, New York: 229- 232.

Cottenie, A.; M. Verloo; M. Velghe and R. Camerlynck (1982). Chemical analysis of plant and soil laboratory of analytical Ayro chemistry. State Univ. Ghant, Belgium.

Douda, S.N.; F.A. Ajayi and E. Ndor (2008): Growth and Yield of water melon (Lantus citrullus) as affected by Poultry Manure application. J.Agric . Soc.Sci.,4:121-211.

EI -Sherbeny, S.E. ; M.Y. Khalil and M.S.Hussein (2007): Growth and productivity of rue (Ruta graveolens) under different foliar fertilizers application. Journal of Applied Sciences Research,3(5):399-407.

El-Hadidy, M.N. and Boluos. I., M.N.and Boluos, L. (1979). Khaya senegalensis A.Juss. street trees in Egypt. Dar Memphis for Printing Cairo. 
El-Salhy, A.M.; A.M.A. El-Sese ; M.F. Badran and Shima H. Gaber (2017). Partial replacement of nitrogen fertilization by humic acid and seaweed extracts in balady mandarin orchards Assiut J. Agric. Sci., 48(4): 185-199.

El-Sayed, A.A. and Abdou, M.A.H. (2002): Response of Khaya transplants to some soil media and biofertilization treatments. Ann. Agric. Sci., Moshtohor, 40 (4): 2233-2245.

Galal, T.G. and B. E. Ali (2004): Bio- fertilization and organic farming approaches: advances in Agriculture research in Egypt. Agriculture Research Center., 5 (1):

Gamal, A. F. (2006). Response of Washington. Novel orange trees to some antioxidants and biofertilization treatments. M. Sc. Thesis Fac. Of Agric., Minia univ., Egypt.

Haggag, Laila, F.; N. S. Mustafa ; M.F.M. Shahin ; E.A.E. Genaidy and H. A. Mahdy (2014). Impact of NPK. Humic acid and algae extract on growth of "Aggizi" Olive seedlings cultured in sand soil under greenhouse conditions. J. of Agric. Technology, 10 (6): 1599- 1606.

Hanafy, M.S. ; F.M. Saadawy ; S.M.N. Milad and R.M. Ali (2012): Effect of some natural extracts on growth and chemical constituents of Schefflera arboricola plants . Journal of Horticultural Science \& Ornamental Plants, 4(1):26-33.

Hassan, E.A. (2015). Influnence of mixed minerals orea and sera red liquid extract on growth , yield and chemical (Anethum graveolens,L.) plants. Middle East J. Applied Sciences, 5:751-758.

Hassan, H.M.I. (2008). Effect of algae Extract on productivity of balady orange trees. M.sc.Thesis . Fac. of agric., Minia Univ., Egypt.

Hegab, M.Y.; A.M.A. Sharwy and S.A.G. El-Saida (2005). Effect of algae Extract and monopotassium phosphate on growth and fruiting of balady orange trees. Bull. Fac. Agric., Cairo Univ., 56:107-210.

Hussien, Sh.H. (2019): Effect of some agricultural treatments on Moringa pregrena plant. Ph.D. Thesis, Fac. Agric. Minia Univ.

Ismail, O.M.; Dakhly, O.F. and Ismail, M.N. (2011). Influence of some bacteria strains and algae as bio-fertilizers on growth of bitter orange seedlings- Australian j.of basic and applied Sci ., 5(11) : 1285-1289.

Jackson (1973): Soil chemical Analysis. Eng lewood cliffs, New Prentice hall Inc., New York

Kamar, M. E. and omar, A. (1987): Effect of nitrogen levels and spraying with animal-forte (amino acids salvation) on yield of cucumber and potatoes. J. Agric. Mansoura univ., 12 (4) 900- 907. 
Kowalczyk, K. and T. Zielony (2008): Effect of Amino plant and Asari on yield and quality of Lettuce grown on Rock Wool. Conf. of bio stimulators in modern agriculture, 7.8 February 2008, Warsaw.

Mahmoud, M.A. (2014): Physiological studies on Poplar trees. Ph.D. Thesis, Fac. Agric. Minia Univ.

Mead, R.N.; R.N. Currow and A.M. Harted (1993). Statistical Methods in agricultural and Experimental Biology, 2nd Ed. Chapman, LondonP.10-44.

Moustafa, M.F. and A.A. El-Hosseiny (2001): Influence of spraying active dry yeast solution on growth,yield ,fruit quality and leaf NPK content of Washington Navel orange tree. J. Agric. Sci. Mansoura Univ., 26(10):6293-6305.

MSTAT- C (1986): A Microcomputer program for the design management and Analysis of Agronomic Research Experiments (version 4.0), Michigan State univ., U.S.A.

Mustafa, H.E.B. and A.F.A. Ebeid (2013): Stimulatory effect of using antioxidant on growth and nutritional status of Albizzia lebbek and taxodium distichum seedlings.Minia J . of Agric.Res\&Develop., 33(1):53-69.

Nagodawithana, W. T. (1991), Yeast Technology, universal foods corporation, Milwaukee, Wisconsin, Von Nostrand Reinhold, New york, U.S.A, PP. 273.

Natarajan, K. (2007), Ponclagavga for plant, Proceedings of national conference on Glory of Gomatha, veterinary university, tirupati., India, PP. 72- 75.

Osman, H.E. and O.M.A. Salem (2011) Effect of seaweed extracts on foliar spray on sunflower yield and oil content. Egyption J. of Phycol., 12: 59- 72.

Pramanick, B.B.; B.B. Brahm ; K. Brahmachori and A. Gosh (2013). Effect of seaweed saps on growth and yield improvement of green gram. African J. of Agric. Res., 8 (13): 180-1186.

Ramarao, K. (1991). Effect of seaweed extract on the ziziphus Mauratinana Lank. J. India Bot. Soc., 71: 19- 21.

Saber, M. S. (1997), Bio-fertilized farming System, Proceeding of the training courseon Bio-Organic Farming Systems for Sustainable Agriculture, Cairo, Egypt, PP. 16- 72.

Saoir, S. and J. Archer (2010). The effect of algaegreen 200(cold-process seaweed liquid extract) on the mineral content of "Bramley $\mathrm{s}$ seedlings apple leaves and fruit. Acta Hort. (ISHS)868:301-306.

Shehata, S.M. ; H.S. Abd-Azem ; A. Abou El-Yazied and A.M. ElGizawy (2011): Effect of foliar spraying with amino acids and seaweed extract on growth, chemical constitutes, yield and its 
quality of celeriac plant.European J.of scientific Research., 58(2): 257-265.

Shoug, M.A. (2019): Behaviour of Balady mandarin trees to some yeast, amino acids and salicylic acid treatment . Ph-Azhar Univ., Assiut.

Smith, T. A. (1982): The function and metabolism of polyamines in higher plants. In; warrig P. F. (Ed.), Plant Growth substances. A cadamic Press, New York.

Sreenivasa, M.N. ; M.N. Najaraj and S.N. Bhat (2010),"Beejarnruth; A source for beneficial bacteria, Kamataka", Journal of Agricultural Science, 17:72-77.

Subba Rao, N.S. (1984),"Bio- fertilizers in Agriculture Oxford IBH. Company. New Delhi.

Suresh, K. D. ; G. Sneh ; K. K. Krishn and C. M. Mool (2004): Microbial biomass carbon and microbial activities of soils receiving chemical fertilizers and organic amendments. Arch. Agrom. Soil Sci., 50: 641- 647.

Taiwo, L.B. ; J.A. Adediran ; O.A. Ashaye ; O. Odofin and A.J. Oyadoyin (2002), "Organic Okra (Abolmoschus esculantus): its growth , yield and organolptic properties" ,Nutrition and food Science ,32 (415):180-183.

Talaat, I.M. (2005): physiological effect of salicylic acid and tryptophan on pelargonium graveolens L .Egypt.J.Appl.Sci.,20:751-760.

Talaat, I.M. ; M.A. Bekheta and M.H. Mahgoub (2005): physiological Response of periwinkle plants (Catharanthus roseus L.) to tryptophan and putrescine.Inter.J.od Agric.and Bio. 7(2):210-213.

Tantawy, A.S. ; A.M.R. Abd El- Mawgoud ; M.A. El- Nemr and Y. Ghorra Chamoun (2009): Alleviation of salinity effects on tomato acids and growth regulators. Europe. H. Sci. Res., 30 (3): 484- 494.

Tarrow, D. and A. Nakase (1975), "DNA bas composition of spaces of the genus saccharomyces",Antonie Van Leeuwenhoek,41,PP.81.

Tung, Y. H. O.; A.Quigg ; Z. V. Finkel ; A. J. Milligan ; K. Wyman ; P. G. Falkowski and F.M.M. Morel (2003). The elemental composition of some marine phytoplankton. J. of phycology, 39 (1): 10- 20.

Turan, K. and M. Kose (2004). Seaweed extract improve copper uptake of grapevine (Vitis vinifera). Acta Agric . Seed , B.Soil plant Sci., 54:213-220.

Verkij, F.N. (1992). Seaweed extracts in agriculture and Horticulture: a review. Biological agriculture and Horticulture, 8:309-324.

Wilde, S.A. ; R.P. Corey ; J.C. Lver and G.K. Voigt (1985): Soil and Plant Analysis for Tree Culture. Oxford IBH. Publishing Co. New Delhi, India. 
William, J. ; K. Boadu and N.B. Baatuuwie (2012): initial growth response of Moringa oleifera seedlings to different soil amendments. Afr. J. Agric. Res., 7 (45): 6082-6086.

Wroblewska, H. ; E. Kozik and M. Czajka (2009): Content of macro and micro components in willow (Salix purpurea L.) grown in substrates with composts of post - use wood waste. Folia Forestalia Polonica Series B, Issue 40, 23-30, 2009.

Yassen, A.A. ; A.A.M. Mazhar and S.M. Zoghloul (2010): Response of Anise Plants to nitrogen Fertilizer and foliar spray of tryptophan under agricultural drainage water. New York Sci.J.,3(9):120-127.

Zhang, X. and R.E. Schmidt (2000): Hormone-containing products' impact on antioxidant status of tall fescue and creeping bentgrass subjected to drought. Crop Science;40(5):1344-9.

دور طين المرشحات والاحماض الامينية والخميرة النشطة ومستخلص الأعشاب

البحرية في تحسين النمو ويعض المكونات الكيميائية لثتلات الكايا السنغالي

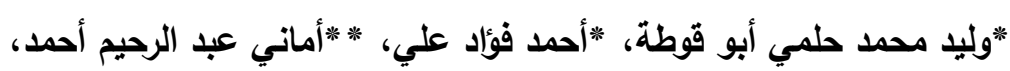

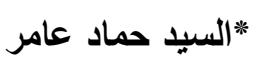

" قسم البساتين - كلية الزراعة - جامعة الازهر - أسيوط

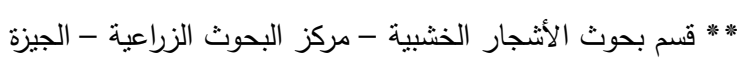

أجري هذا البحث في مزرعة كلية الزراعة - جامعة الازهر - فرع أسيوط خلال موسمي

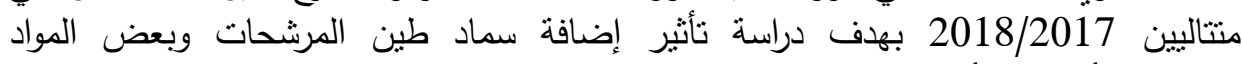

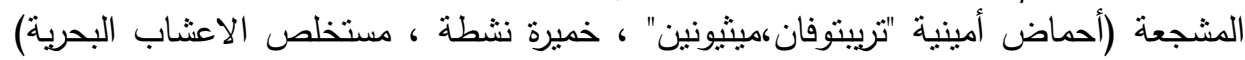

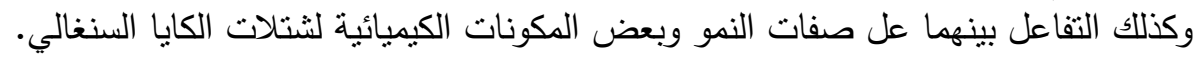

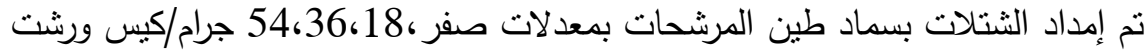

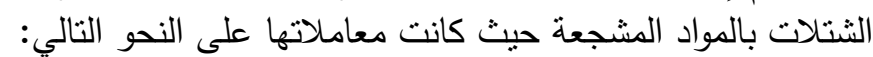

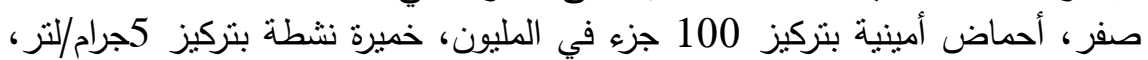

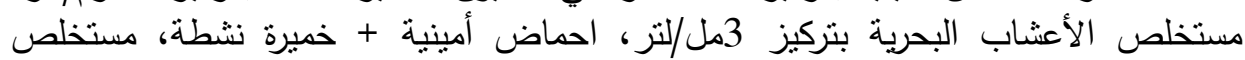

الأعثاب البحرية + خميرة نثطة، أحماض أمينية + مستخلص الأعثاب البحرية، أحماض البطرة أمينية + خميرة نثطة + مستخلص الأعثاب البحرية.

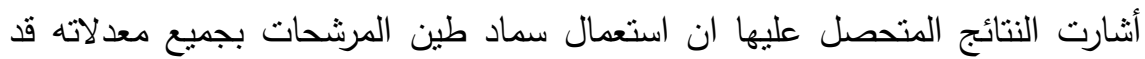

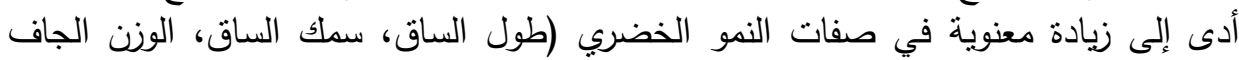

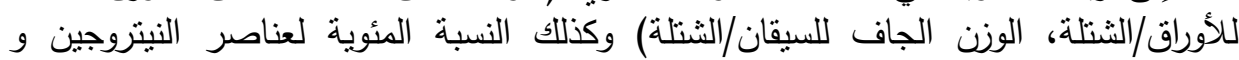
الفوسفور و البوتاسيوم باستثاء المعدل المنذفض من طين المرشحات (18 جرام/الثنلة) في

ولقد تم الحصول أغلب أقتيم من هذه الصفات عند إضافة المعدل التالي من طين

المرشحات (54جرام/ثنتلة) .في كثير من الحالات أدى رش الثنتلات بالمواد المنشطة سواء 
بصورة منفردة أو خليطة إلى حدوث زيادة معنوية في الصفات تحت الدراسة - أفضل النتائج نم

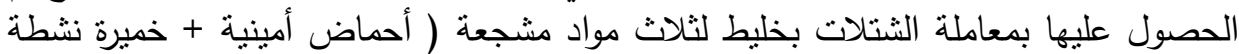

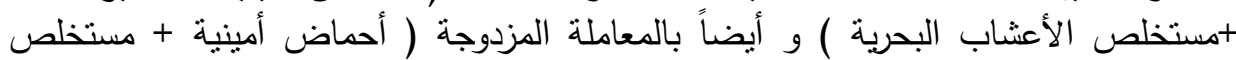

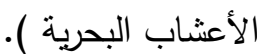

أدت معظم معاملات التداخل إلى زيادة معنوية لصفات النمو و النسبة المئوية لعناصر

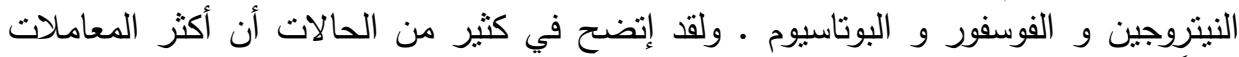

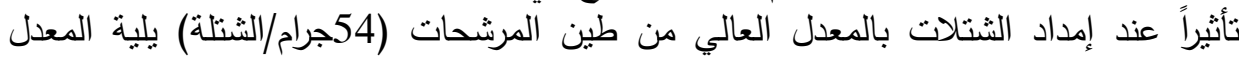

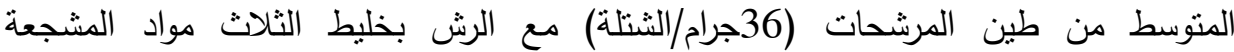
( أحماض أمينية +خميرة نشطة + مستخلص الأعشاب البحرية و المعاملة المزدوجة ( أحماض الماض

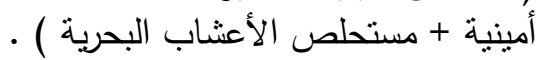

